\title{
Abundance and diversity of Mollusca in the Beagle Channel*
}

\author{
KATRIN LINSE \\ Zoological Institute and Zoological Museum, University of Hamburg, Martin-Luther-King-Platz 3, \\ D-20146 Hamburg, Germany.
}

\begin{abstract}
SUMMARY: The malacofauna of the Beagle Channel caught by an epibenthic sledge during the Joint Magellan "Victor Hensen" Campaign in 1994 was investigated. At 11 locations 16 samples were taken on a transect through the Channel. Species of Aplacophora, Polyplacophora, Gastropoda, Scaphopoda and Bivalvia were identified and quantified. Their horizontal and vertical distribution was described and possible reasons due to their feeding mode discussed. The exact number of specimens collected was 35,084 yielding 107,208 molluscs/ $1000 \mathrm{~m}^{2}$.
\end{abstract}

Key words: Mollusca, abundance, feeding mode, Beagle Channel

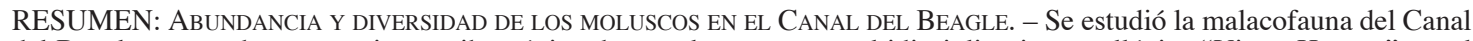
del Beagle capturada por un trineo epibentónico durante la campaña multidisciplinaria magallánica "Victor Hensen", en el año 1994. Se tomaron 16 muestras en 11 estaciones mediante un transecto a lo largo del Canal. Se identificaron especies de aplacóforos, polyplacóforos, gasterópodos, escafópodos y bivalvos, y se cuantificó su abundancia. Se describe la distribucion horizontal y vertical, justificando esta, en parte, por su modo de alimentación. Se capturaron 35.084 individuos, lo que correspondería a 107.208 moluscos por $1000 \mathrm{~m}^{2}$.

Palabras clave: Moluscos, abundancia, modo de alimentación, Canal del Beagle.

\section{INTRODUCTION}

From the middle of the 19th century onwards many expeditions have led to the Magellan region. Most of them focused on taxonomic studies (e.g. King and Broderip, 1831; Smith, 1885; Mabille and Rochebrune, 1889; Strebel, 1904, 1905a, b, 1906, 1907, 1908; Soot-Ryen, 1959; Dell, 1971). Chilean and Argentinian scientists like Gallardo (e.g. 1979) or de Castellanos (e.g. 1988-93) focused on reproduction and taxonomy, respectively. Brattström and

\footnotetext{
*Accepted January 29, 1999.
}

Johanssen (1983) published ecological investigations carried out in southern Chile. Bastida et al. (1992) worked on benthic community structure including molluscs on the Argentine continental shelf.

In the southern summers 1989-90 and 1990-91 joint Chilean-Italian expeditions were carried out in the Magellan region with a focus on the Straits of Magellan and a preliminary investigation of the Beagle Channel (Brambati, 1992). Di Geronimo et al. (1993) worked on molluscan thanatocenoses.

The "Joint Magellan "Victor Hensen" Campaign 1994" (Arntz and Gorny, 1996) was the first expedi- 


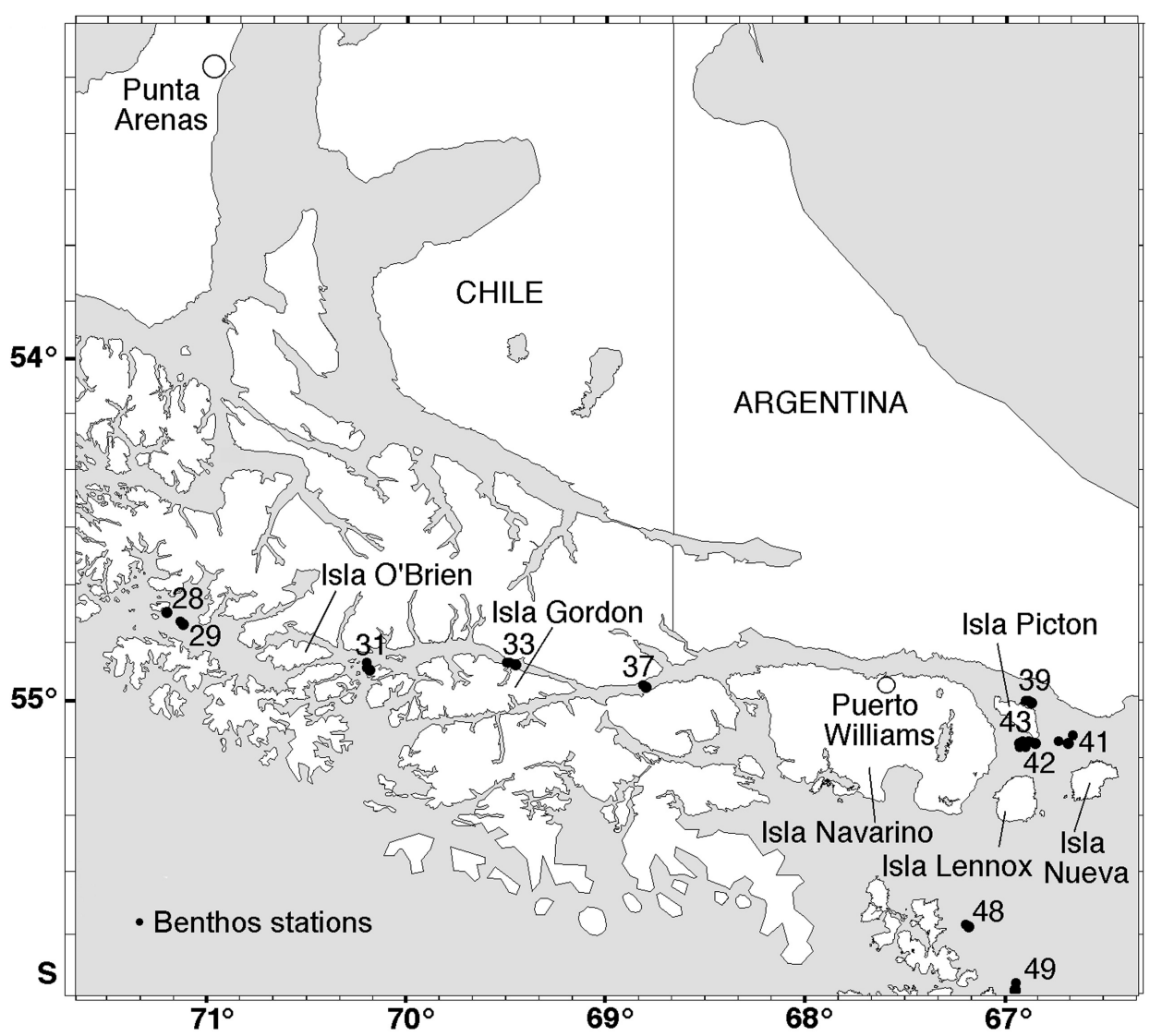

FIG. 1. - EBS stations on the transect through the Beagle Channel (modified after Arntz and Gorny, 1996) Abbreviations: 28 C. Ballenero, off Punta Baja, 29 C. Ballenero, 31 C. Beagle, I. Timbal Chico, 33 C. Beagle Romanche, 37 C. Beagle, 39. I. Gardiner, 41 SE I. Picton, 42 Pta Rico, 43 I. Picton, 48 I. Wollaston, 49 off Islas Barnevelt.

tion that focused on benthos studies in the Beagle Channel. The present study is based on molluscan samples collected during the "Joint Magellan" expedition by means of an epibenthic sledge.

This epibenthic sledge (EBS) collects small epiand suprabenthic macrofauna. One taxon in focus were the molluscs collected with this gear. Bivalves were most abundant and diverse with 26,461 individuals and 52 species, followed by Gastropoda with 5,075 individuals and also 52 species. Aplacophora occurred with 1,456 individuals and 9 species, Polyplacophora with 1,515 individuals and Scaphopoda with 579 individuals and 5 species (Linse, 1997). The aim of the present investigation is to describe the distribution of molluscs in the Beagle Chanel.

\section{MATERIAL AND METHODS}

On a transect from off the eastern entrance through the Beagle Channel to the western entrance (Fig.1) macrobenthic Mollusca were collected. The samples were taken by means of an epibenthic sledge (EBS) (Rothlisberg and Pearcy, 1977) which was improved by Brandt and Barthel (1995) in order to catch both the epibenthic and the benthic-boundary-layer fauna. The sledge carries a sampling box with an opening of $100 \mathrm{~cm}$ width and $33 \mathrm{~cm}$ height. A $0.5 \mathrm{~mm}$ plankton net is attached to each sampler, the cod end is enclosed by a $0.3 \mathrm{~mm}$ mesh net. When the sledge touches the seafloor a shovel fixed to the box door of the epibenthic sampler opens the box. The doors are closed when the sledge leaves the bottom. The sledge was hauled over the ground for 10 min at a mean velocity of 1 knot. The haul distances were calculated on the basis of the GPS-derived positions of the ship at the start and end of the haul distance in $\mathrm{m}=1852 \sqrt{\left(\Delta l a t^{\prime}\right)^{2}+\left(\cos l a t^{\prime} \times \Delta \text { long }^{\prime}\right)^{2}}$

after Brattegard (pers. comm.) and Brandt and Barthel (1995). The haul length varied from 132 to $608 \mathrm{~m}$ (Table 1), therefore the numbers of individuals are calculated for standardized $1000 \mathrm{~m}$ hauls. 16 stations were sampled at 11 sample locations (Table 1). The result at station 33-1261 might be an artifact 
TABLE 1. - Station list of the EBS samples from the Beagle Channel (from Brandt et al., 1997).

\begin{tabular}{|c|c|c|c|c|c|c|c|c|}
\hline \multirow[t]{2}{*}{ Station } & \multirow[t]{2}{*}{ Date } & \multicolumn{4}{|c|}{ Position } & \multirow{2}{*}{$\begin{array}{c}\text { Depth } \\
(\mathrm{m})\end{array}$} & \multirow{2}{*}{$\underset{(\mathrm{m})}{\mathrm{Haul}}$} & \multirow[t]{2}{*}{ Sediment } \\
\hline & & $\mathrm{S}$ beg. (lat) & $S$ end & W beg. (long) & W end & & & \\
\hline \multicolumn{9}{|l|}{ west } \\
\hline $28 *-1279$ & $11 / 21 / 94$ & $54^{\circ} 46,84$ & $54^{\circ} 46,90$ & $71^{\circ} 08,48$ & $71^{\circ} 08,35$ & 580 & 178 & fine terrigenous sediment \\
\hline $29 *-1270$ & $11 / 21 / 94$ & $54^{\circ} 55,17$ & $54^{\circ} 55,23$ & $70^{\circ} 45,15$ & $70^{\circ} 44,81$ & 135 & 379 & coarse stony shells, foraminifera \\
\hline $31 *-1263$ & $11 / 20 / 94$ & $54^{\circ} 54,04$ & $54^{\circ} 54,00$ & $70^{\circ} 12,76$ & $70^{\circ} 12,52$ & 665 & 266 & mud and crushed shells \\
\hline $33 *-1261$ & $11 / 20 / 94$ & $54^{\circ} 53,64$ & $54^{\circ} 53,81$ & $69^{\circ} 58,98$ & $69^{\circ} 59,03$ & 120 & 319 & sponge spicules \\
\hline $33 *-1257$ & $11 / 19 / 94$ & $54^{\circ} 53,43$ & $54^{\circ} 53,32$ & $69^{\circ} 30,94$ & $69^{\circ} 31,14$ & 350 & 295 & Foraminifera \\
\hline $37 *-1253$ & $11 / 19 / 94$ & $54^{\circ} 55,12$ & $54^{\circ} 55,11$ & $69^{\circ} 19,89$ & $69^{\circ} 20,13$ & 265 & 256 & very fine mud \\
\hline $37 *-1248$ & $11 / 19 / 94$ & $54^{\circ} 58,80$ & $54^{\circ} 58,78$ & $69^{\circ} 01,75$ & $69^{\circ} 01,98$ & 217 & 247 & fine mud and sand \\
\hline $37 *-1247$ & $11 / 19 / 94$ & $54^{\circ} 59,43$ & $54^{\circ} 59,51$ & $69^{\circ} 04,64$ & $69^{\circ} 04,28$ & 100 & 410 & fine mud, coarse stones, foraminifera \\
\hline $37 *-1246$ & $11 / 19 / 94$ & $54^{\circ} 58,00$ & $54^{\circ} 57,85$ & $68^{\circ} 49,31$ & $68^{\circ} 49,04$ & 253 & 400 & very fine mud \\
\hline $39 *-1237$ & $11 / 18 / 94$ & $55^{\circ} 00,51$ & $55^{\circ} 00,48$ & $66^{\circ} 53,14$ & $66^{\circ} 53,29$ & 103 & 169 & very fine mud \\
\hline $41 *-1213$ & $11 / 15 / 94$ & $55^{\circ} 06,89$ & $55^{\circ} 06,72$ & $66^{\circ} 39,95$ & $66^{\circ} 39,92$ & 63 & 316 & crushed mollusc shells \\
\hline $42 *-1178$ & $11 / 12 / 94$ & $55^{\circ} 07,30$ & $55^{\circ} 07,28$ & $66^{\circ} 52,78$ & $66^{\circ} 52,90$ & 25 & 132 & red algae and crushed Cirripedia fragments \\
\hline $43 *-1194$ & $11 / 13 / 94$ & $55^{\circ} 08,48$ & $55^{\circ} 08,19$ & $66^{\circ} 57,81$ & $66^{\circ} 58,08$ & 118 & 608 & fine mud \\
\hline $43 *-1184$ & $11 / 12 / 94$ & $55^{\circ} 06,84$ & $55^{\circ} 06,95$ & $66^{\circ} 55,54$ & $66^{\circ} 55,67$ & 110 & 246 & no sediment sampled \\
\hline $48 *-1200$ & $11 / 14 / 94$ & $55^{\circ} 38,52$ & $55^{\circ} 38,57$ & $67^{\circ} 12,86$ & $67^{\circ} 13,26$ & 40 & 428 & crushed mollusc shells \\
\hline $49 *-1206$ & $11 / 14 / 94$ & $55^{\circ} 48,13$ & $55^{\circ} 48,10$ & $66^{\circ} 58,45$ & $66^{\circ} 58,62$ & 66 & 186 & fine crushed mollusc shells \\
\hline east & & & & & & & & \\
\hline
\end{tabular}

* = for station data see Fig.1

due to a failure, because the vessel steamed with 3 knots instead of 1 knot and turned in the channel; therefore the sledge might have left the bottom for some time. At station 28-1279 the plankton net was slightly damaged but as the cod end was intact the sample was considered to be complete.

When the samples reached the deck of the vessel, they were washed on a $300 \mu \mathrm{m}$ screen. The complete samples were fixed in $4 \%$ buffered formaldehyde and later transferred into $70 \%$ ethanol. All molluscs from the samples were analyzed for the comparison of the 16 stations.
Aplacophora, Gastropoda, Scaphopoda and Bivalvia were counted and identified (e.g. de Castellanos, 1988-1993; Dell, 1964; Hain, 1990; SootRyen, 1959; Strebel, 1904, 1905a, b, 1906, 1907, 1908), Polyplacophora were only counted, their identification is still in progress (Table 2).

Information about the feeding mode was taken from the literature (e.g. Hain, 1990) or personal dissection of stomach contents. Most species with unknown feeding modes are bivalves, and most of these will be filter feeders.

In this paper various components of "species

TABLE 2. - Molluscan abundance and species richness (per station). Abbreviations: Polyplac $=$ Polyplacophora; $\mathrm{n}=$ number of specimens per station; $\mathrm{n} / 1000 \mathrm{~m}^{2}=$ number of specimens per station calculated for $1000 \mathrm{~m}^{2}$ trawled area; $\mathrm{S}=$ species numbers.

\begin{tabular}{|c|c|c|c|c|c|c|c|c|c|c|c|c|}
\hline Station & $\begin{array}{l}\text { Aplacophora } \\
\mathrm{n} \backslash \mathrm{n} / 1000 \mathrm{~m}^{2}\end{array}$ & $\mathrm{~S}$ & $\begin{array}{c}\text { Polyplaco } \\
\mathrm{n} \backslash \mathrm{n} / 1000 \mathrm{~m}^{2}\end{array}$ & $\mathrm{~S}$ & $\begin{array}{l}\text { Gastropoda } \\
\mathrm{n} \backslash \mathrm{n} / 1000 \mathrm{~m}^{2}\end{array}$ & S & $\begin{array}{l}\text { Scaphopoda } \\
\mathrm{n} \backslash \mathrm{n} / 1000 \mathrm{~m}^{2}\end{array}$ & $\mathrm{~S}$ & $\begin{array}{c}\text { Bivalvia } \\
\mathrm{n} \backslash \mathrm{n} / 1000 \mathrm{~m}^{2}\end{array}$ & $\mathrm{~S}$ & $\begin{array}{c}\text { Mollusca } \\
\mathrm{n} \backslash \mathrm{n} / 1000 \mathrm{~m}^{2}\end{array}$ & $\mathrm{~S}$ \\
\hline \multicolumn{13}{|l|}{ west } \\
\hline $28-1279 *$ & $37 \backslash 208$ & 4 & $5 \backslash 28$ & - & $5 \backslash 28$ & 7 & $7 \backslash 39$ & 3 & $42 \backslash 236$ & 8 & $91 \backslash 534$ & 19 \\
\hline $29-1270$ & - & - & $3 \backslash 8$ & & $14 \backslash 34$ & 11 & $19 \backslash 53$ & 2 & $611 \backslash 1612$ & 17 & $647 \backslash 1707$ & 30 \\
\hline $31-1263$ & $567 \backslash 2244$ & 5 & - & - & $143 \backslash 538$ & 7 & $228 \backslash 857$ & 4 & $4682 \backslash 17605$ & 21 & $5620 \backslash 21244$ & 37 \\
\hline $33-1261 *$ & - & - & - & - & - & - & - & - & $10 \backslash 31$ & 5 & $10 \backslash 31$ & 5 \\
\hline $33-1257$ & $2 \backslash 7$ & 1 & - & - & - & - & $1 \backslash 3$ & 1 & $53 \backslash 180$ & 5 & $56 \backslash 190$ & 7 \\
\hline $37-1253$ & - & - & - & - & $75 \backslash 293$ & 3 & $9 \backslash 35$ & 1 & $160 \backslash 680$ & 13 & $244 \backslash 1008$ & 17 \\
\hline $37-1248$ & $5 \backslash 20$ & 4 & - & - & $13 \backslash 32$ & 6 & $103 \backslash 417$ & 1 & $366 \backslash 1482$ & 19 & $487 \backslash 1951$ & 30 \\
\hline $37-1247$ & $29 \backslash 71$ & 7 & $82 \backslash 183$ & & $122 \backslash 222$ & 17 & $2 \backslash 5$ & 1 & $709 \backslash 1729$ & 23 & $314 \backslash 2210$ & 48 \\
\hline $37-1246$ & $583 \backslash 1458$ & 5 & $1 \backslash 3$ & & $124 \backslash 310$ & 4 & $207 \backslash 468$ & 5 & $14295 \backslash 35688$ & 22 & $15210 \backslash 37927$ & 36 \\
\hline $39-1237$ & - & - & $2 \backslash 12$ & & $5 \backslash 30$ & 4 & - & - & $306 \backslash 1811$ & 12 & $313 \backslash 1853$ & 16 \\
\hline $41-1213$ & $233 \backslash 737$ & 3 & $1293 \backslash 4092$ & & $3015 \backslash 9500$ & 36 & - & - & $2653 \backslash 8392$ & 30 & $6094 \backslash 22721$ & 69 \\
\hline $42-1178$ & - & - & $10 \backslash 76$ & & $106 \backslash 788$ & 12 & - & - & $54 \backslash 409$ & 16 & $170 \backslash 1273$ & 28 \\
\hline $43-1194$ & - & - & - & - & - & - & - & - & $2 \backslash 3$ & 2 & $2 \backslash 3$ & 2 \\
\hline $43-1184$ & - & - & $1 \backslash 4$ & & $5 \backslash 20$ & 3 & - & - & $261 \backslash 1061$ & 5 & $267 \backslash 1085$ & 8 \\
\hline $48-1200$ & - & - & $123 \backslash 287$ & & $746 \backslash 1731$ & 25 & - & - & $1462 \backslash 3416$ & 19 & $2331 \backslash 5424$ & 44 \\
\hline $\begin{array}{l}49-1206 \\
\text { east }\end{array}$ & - & - & - & - & $702 \backslash 3763$ & 14 & - & - & $795 \backslash 4274$ & 10 & $1497 \backslash 8037$ & 24 \\
\hline
\end{tabular}

$*=$ possible failures. 

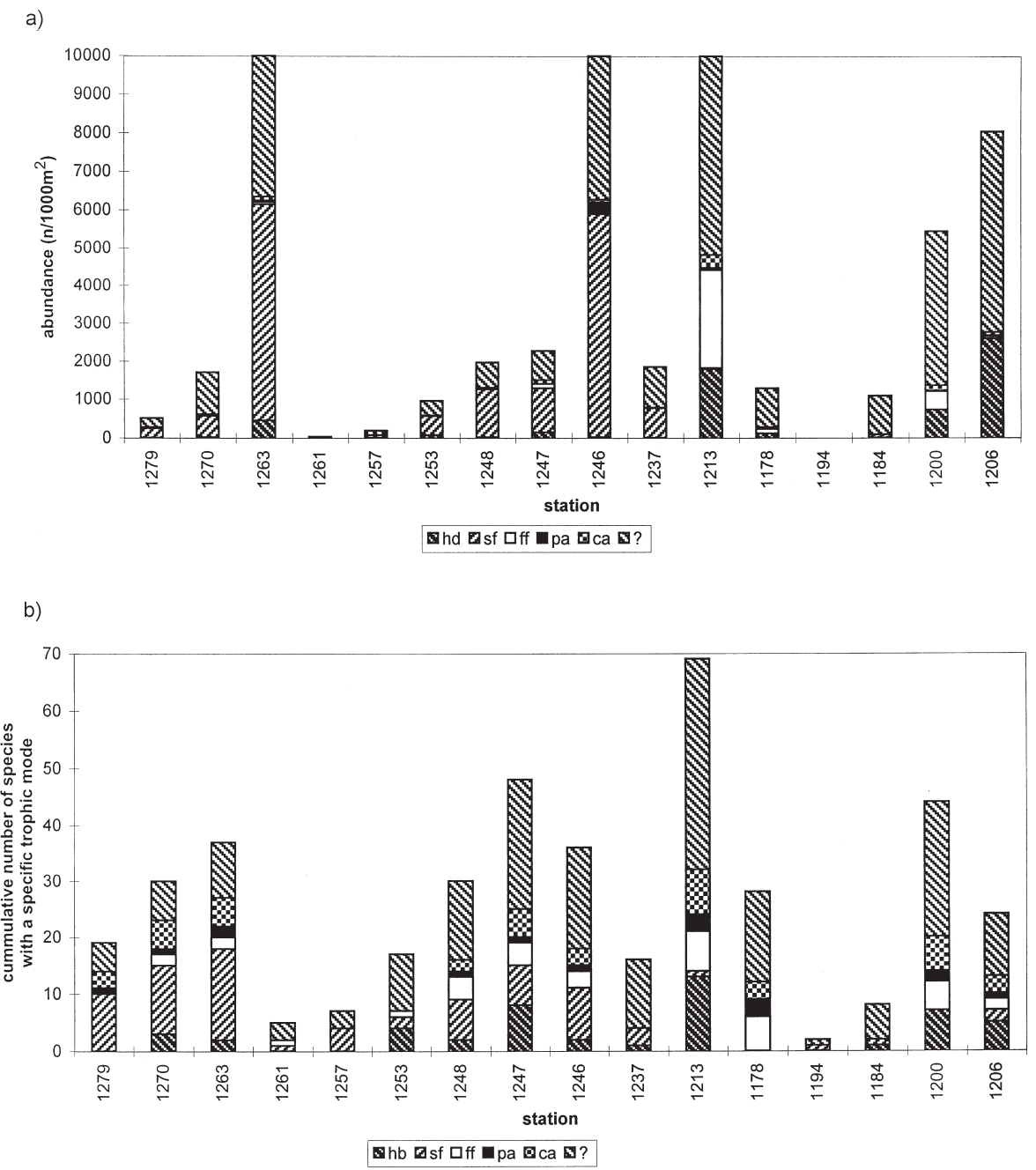

FIG. 2. - (A) abundance of molluscs and (B) number of species with a specific trophic mode, calculated per station from west to east through the Beagle Channel. hd = herbi- or detritivores; $\mathrm{sb}=$ substrate feeders; $\mathrm{ff}=$ filter feeders; $\mathrm{pa}=$ parasites; $\mathrm{ca}=$ carnivores; $?=$ feeding mode unknown.

diversity" are used: species richness, i.e. the number of species sampled at a station (Hurlbert, 1971); the Shannon-Wiener index of diversity H' (using $\log _{e}$; Shannon and Weaver, 1949), and the evenness J (Pielou, 1966) were estimated for each sampling station.

\section{RESULTS}

In total 35,084 specimens belonging to 118 species of 86 genera and 58 families were collected. For comparisons between stations samples were standardized for $1000 \mathrm{~m}^{2}$ hauls, yielding a total of 107,208 individuals (Table 2).

The molluscan abundances differed strikingly between hauls ranging from three to over 10,000 individuals $/ 1000 \mathrm{~m}^{2}$ (Table 2, Fig.2a). The highest abundances were found at the deepest station 31-1263, at station 37-1246 in the inner channel and at station 411213 at the eastern entrance of the Beagle. Abundance was low at the other stations; only the stations off the eastern entrance (Stns. 48-1200, 49-1206) showed a higher number of specimens (Table 2).

At stations at and off the eastern entrance herbivorous, detritivorous and filter feeding taxa were very abundant (Fig.2a) compared with bivalve taxa with an unknown feeding mode such as species of Cyamiidae, Neoleptonidae, and Carditidae. At stations in the inner Channel substrate feeding taxa were more important in terms of specimen numbers. The high abundance of taxa with an unknown feeding mode refers to 3 very abundant species of the families Thyasiridae and Erycinidae (Fig. 2a).

Species richness varied between stations, ranging from 2 to 69. It was highest at Stn 41-1213 off the eastern entrance and also quite high at Stn. 37-1247 in the inner channel (Table 2, Fig.2b). 


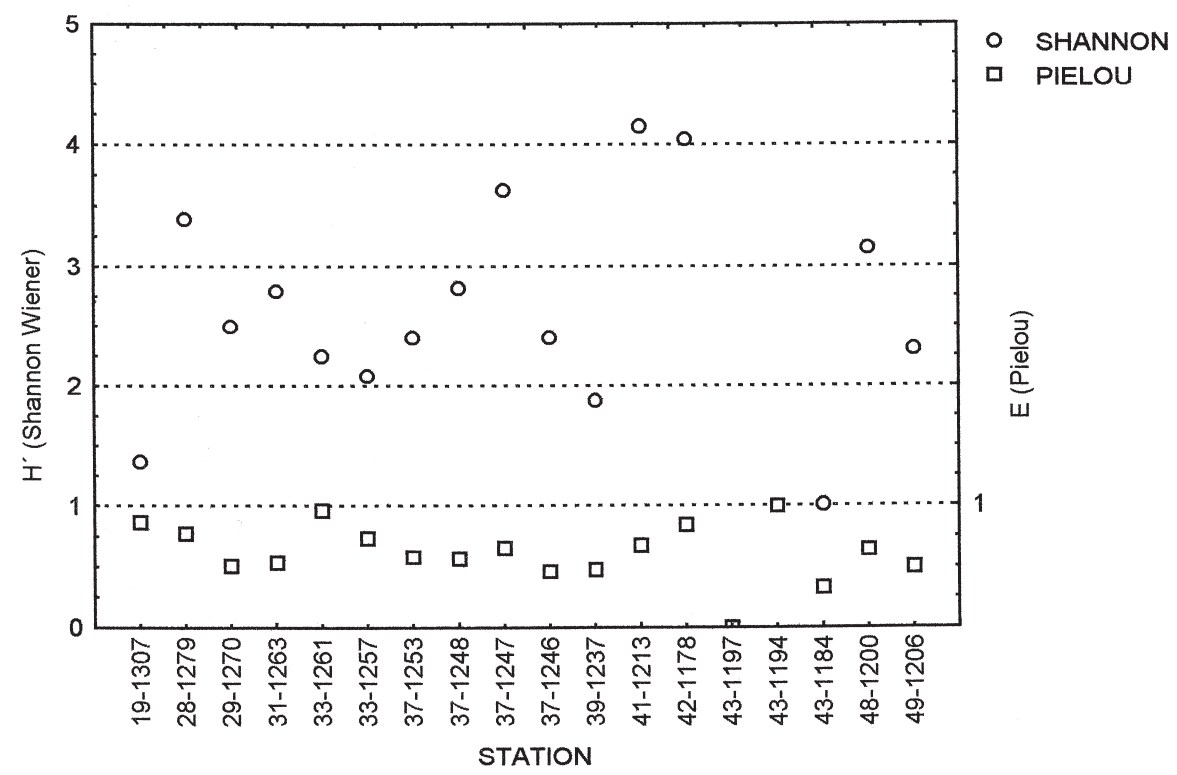

FIG. 3. - Molluscan Shannon-Wiener index of diversity H' (Shannon and Weaver, 1949) and evenness J (Pielou, 1966) per station from west to east through the Beagle Channel.

TABLE 3. - Molluscan abundances $\left(\mathrm{n} / 1000 \mathrm{~m}^{2}\right)$ with depth. Abbreviations: Aplac $=$ Aplacophora $;$ Poly $=$ Polyplacophora $;$ Gastr $=$ Gastropoda; Scaph = Scaphopoda; Biv = Bivalvia.

\begin{tabular}{lrrrrr}
\hline Depth (m) & Aplac & Poly & Gastr & Scaph & Biv \\
\hline $25-100$ & 808 & 4638 & 16504 & 5 & 18120 \\
$103-135$ & 0 & 24 & 84 & 53 & 4518 \\
$217-271$ & 1458 & 3 & 635 & 929 & 37856 \\
$350-665$ & 2459 & 0 & 566 & 922 & 18021 \\
\hline
\end{tabular}

Polyplacophora and Gastropoda were most frequently sampled down to $200 \mathrm{~m}$. Scaphopoda, however, occurred predominantly at deeper stations (200->300 m). Higher abundances of Aplacophora and Bivalvia were also found at deeper stations but these taxa occurred in shallow water too (Table 3).

At and off the eastern entrance the ShannonWiener diversity H' varied between 1.0 and 4.2 and $\mathrm{J}$ between 0.5 and 1.0 , in the inner channel $\mathrm{H}^{\prime}$ varied between 1.9 and 3.6 and $\mathrm{J}$ between 0.5 and 1.0.

\section{DISCUSSION}

The abundance and species richness of the molluscs varied significantly (Figure 2, Table 2) among the stations on the longitudinal transect. This patchy distribution observed in the Beagle Channel could be caused by food availability, feeding mode or sediment composition.

Brandt et al. (1997) found that stations in the Beagle Channel and off the eastern entrance were characterized by great abundances of small taxa such as Mollusca and Peracarida whereas larger epibenthic macrofauna such as Echinodermata, Anthozoa or Porifera is often absent (Gutt and Schickan, 1996; Gutt, pers. comm.; Witte, 1996). The absence of large filter feeding taxa could increase the presence of small taxa, because, as in the Magdalena Channel (Gutt and Schickan, 1996; Linse and Brandt, 1998) large filter feeders might reduce the amount of particulate organic matter in the benthic boundary layer available for other benthic taxa. Food competition could occur between vagile taxa such as Amphipoda or Mysidacea that can feed in the water column and epi- and endobenthic Mollusca that are restricted to feeding on particles at the sediment surface. At stations (Stns. 371253, 39-1237) with high peracarid abundance especially of vagile Amphipoda (Brandt et al., 1997) molluscan abundance was low. The few occurring molluscs were mostly substrate feeding bivalves like Ennucula grayi (Orbigny, 1846) and Yoldiella granula (Dall, 1908) or Lucinoma lamellata (Smith, 1881). Conversely, off the eastern entrance and in the eastern entrance both taxa (Peracarida and Mollusca) were highly abundant. At these stations (Stns. 41-1213, 48-1200, 49-1206) herbivorous, detritivorous and filter feeding molluscs like Colpospirella algida (Melville and Standen, 1912), Margarella violacea (King and Broderip, 1831), Calliostoma sp., Crenella sp. and Limatula pygmaea (Philippi, 1845) occurred in high numbers, as well as other dominant species with unknown feeding mode, such 
as rissoiform gastropods or the bivalves Cyamiocardium denticulatum (Smith, 1907), Neolepton falklandicum Dell, 1964 and N. umbonatum (Smith, 1885).

The elevated molluscan abundance at stations 31-1263 and 37-1246 refers to high individual numbers of substrate feeding bivalves like E. grayi, Yoldia chilenica (Dall, 1908), Propeleda longicauta$d a$ (Thiele, 1912) and Tindaria virens Dall, 1889 or Lasea sp. with an unknown feeding mode. These five species comprise $73 \%$ and $84 \%$ of the stations' respective specimen number.

A possible reason for the high densities at these stations might be a more favourable food supply. Witte (pers. comm.; Linse, 1997) found that Chlorophyll $a$ and especially phaeopigment concentrations are favourable in the upper centimetres of sediment. Gutt and Schickan (1996) and Witte (1996) mentioned "a thick layer of fluff" (deposited organic matter) occurring on the sediment of the sample locations in the Beagle Channel. Food availability does not seem to be a limiting factor in the Beagle Channel during southern spring.

Different depth ranges of the molluscan species may also be related to their feeding mode. Herbivorous taxa such as the gastropod families Trochidae (e.g. Calliostoma spp.) or Cerithiidae were highly abundant down to $100 \mathrm{~m}$ depth (Table 3). Deeper than $100 \mathrm{~m}$ they occurred only rarely, with two to eight specimens at some stations.

Filter- and sediment feeding species, such as Caudofoveata of the genera Limifossor, Falcidens or Chaetoderma, Scaphopoda (e.g. Fissidentalium majorinum (Mabille and Rochebrune, 1889), Cadulus dalli Pilsbry and Sharp, 1898) and most Bivalvia showed a higher degree of eurybathy. They range over more than $500 \mathrm{~m}$ in depth in the EBS samples and some have a range of over 1000 $m$ in depth (Hain, 1990, Linse, 1997). Some taxa, like the gastropod Admete magellanica Strebel, 1905 or the bivalve Neolepton umbonatum, seem to prefer shallow water depth (as deduced from their abundance), but also occur in deeper water (Linse, 1997). Vertical distribution of predators such as Metheutria martensi Strebel, 1905, Lamellaria ampla Strebel, 1906, L.elata Strebel, 1906 (Gastropoda), Poromya mactroides Dall, 1889 and Cuspidaria chilensis (Dall, 1908) (Bivalvia), and parasites, like the gastropod genera Balcis, Strombiformis or Turbonilla (Gastropoda), depends on the presence of either prey or hosts. For example Balcis subantarcticus (Strebel, 1908) and Strombi- formis carforti Rochebrune and Mabille, 1889, ectoparasites on Echinodermata, occurred at stations (e.g. 31-1263, 37-1247), where irregular sea urchins were sampled (personal observation). The carnivores Poromya and Cuspidaria, which are known to be eurybathic (Hain, 1990) and deep-sea taxa, were mostly found below $250 \mathrm{~m}$ depth (Linse, 1997). These deep, soft-bottom stations contained many crushed, drilled shells of Nucula sp.1 and Yoldia chilenica.

\section{ACKNOWLEDGEMENTS}

The author is grateful to the Alfred Wegener Institute for Polar and Marine Research for financial support for sorting the samples and to W. Arntz and M. Gorny for an earlier version of the Beagle Channel map (Figure 1). Thanks are due to three unknown referees for their comments on the previous manuscript. Supported by the DFG (German Science Foundation), grant Br. 1121/4-1.

\section{REFERENCES}

Arntz, W. and M. Gorny. - 1996. Cruise report of the Joint ChileanGerman-Italian Magellan ,Victor Hensen“ Campaign in 1994. Ber. Polarforsch., 190: 1-113.

Bastida, R., A. Roux and D.E. Martinez. - 1992. Benthic communities of the Argentine continental shelf. Oceanol. Acta, 15: 687-698.

Brambati, A. - 1992. Introduction to the Magellan Project. Boll. Ocean. Teor. Appl., IX, 2/3: 83-92.

Brandt, A. and D. Barthel. - 1995. An improved supra- and epibenthic sledge for catching Peracarida (Crustacea, Malacostraca). Ophelia, 43: 15-23.

Brandt, A., K. Linse and U. Weber. - 1997. Abundance and diversity of peracarid taxa (Crustacea, Malacostraca) along a transect through the Beagle Channel, Patagonia. Polar Biol., 18:83-90.

Brattström, T. and A. Johanssen. - 1983: Ecological and regional zoogeography of the marine fauna of Chile. Sarsia, 68: 289339.

de Castellanos, Z.J.A. - 1988-93. Catálogo Descriptivo de la Malacofauna Magellánica. Parts 1-12. Comisión Invest. Cient. Provincia de Buenos Aires

Dell, R.K. - 1964. Antarctic and sub-Antarctic Mollusca: Amphineura, Scaphopoda, and Bivalvia. Disc. Rep., 23: 93250 .

Dell, R.K. - 1971. The marine Mollusca of the Royal Society Expedition to southern Chile, 1958-59. Rec. Dom. Mus. (Wellington), 7 (17): 155-233.

Di Geronimo, I., S. Privitera and C. Valdovinos. - 1993. Molluscan thanatocoenoses of the Magellan Strait. Nat. Sc. Com. Ant. Magellan Cruise Data Rep., II: 297-306.

Gallardo, C.S. - 1979. Development pattern and adaptations for reproduction in Nucella crassilabrum and other muricacean gastropods. Biol. Bull., 157 (3): 453-463.

Gutt, J. and T. Schickan. - 1996. Epibenthic communities analyzed by underwater camera. Ber. Polarforsch., 190: 35-41.

Hain, S. - 1990. Die beschalten Mollusken (Gastropoda und Bivalvia) des Weddellmeeres, Antarktis. Ber. Polarforsch., 70 : $1-181$.

Hurlbert, S.H. - 1971. The nonconcept of species diversity: a critique and alternative parameters. Ecology, 52: 577-586. 
King, P.P. and W.J. Broderip. - 1831. Description of the Cirrhipedia, Conchifera and Mollusca formed by the officers of H.M.S. Adventure and Beagle employed between the years 1826 and 1830 in surveying the southern coasts of South America including the Straits of Magelhaens and the coast of Tierra del Fuego. Zool. J., 5: 332-349.

Linse, K. - 1997. Die Verbreitung epibenthischer Mollusken im chilenischen Beagle-Kanal. Ber. Polarforsch., 228: 1-131.

Linse, K. and A. Brandt. - 1998. Distribution of epibenthic Mollusca on a transect through the Beagle Channel (southern Chile). $J$. Mar. Biol. Ass. U.K., 78: 875-889.

Mabille, J. and A.T. Rochebrune. - 1889. Mollusques. Mission scientifique du Cap Horn, 1882-3., 6, Zool. 2: 1-143.

Pielou, E.C. - 1966. The measurement of species diversity in different types of biological collections. J. theor. Biol., 13: 131-144.

Rothlisberg, P.C. and W.G. Pearcy. - 1977. An epibenthic sampler used to study the ontogeny of vertical migration of Pandalus jordani (Decapoda, Caridea). Fish. Bull., 74: 994-997.

Shannon C.E. and W. Weaver. - 1949. The Mathematical Theory of Communication. University of Illinois Press, Urbana.

Smith, E.A. - 1885. Report on the Lamellibranchiata collected by H.M.S. "Challenger" during the years 1873-1876. Rep. Sci.
Res. Voy. “Challenger” (1873-1876), Zool., 13: 1-341.

Soot-Ryen, T. - 1959. Pelecypoda. Lunds Univ. Arsskrift, 55 (6): 186.

Strebel, H. - 1904. Beiträge zur Kenntnis der Mollusken Fauna der Magalhaen Provinz. Zool. Jahrb. Abt. Syst., Geogr. Biol., Jena, 21: 171-248.

Strebel, H. - 1905 a. Beiträge zur Kenntnis der Mollusken Fauna der Magalhaen Provinz. II. Die Trochiden. Zool. Jahrb. Abt. Syst., Geogr. Biol., Jena, 21, Suppl. VIII: 121-166.

Strebel, H. - 1905 b. Beiträge zur Kenntnis der Mollusken Fauna der Magalhaen Provinz. 3. Zool. Jahrb. Abt. Syst., Geogr. Biol., Jena, 22: 575-666.

Strebel, H. - 1906. Beiträge zur Kenntnis der Mollusken Fauna der Magalhaen Provinz. 4. Zool. Jahrb. Abt. Syst., Geogr. Biol., Jena, 24: 91-174.

Strebel, H. - 1907. Beiträge zur Kenntnis der Mollusken Fauna der Magalhaen Provinz. 5. Zool. Jahrb. Abt. Syst., Geogr. Biol., Jena, 25: 79-196.

Strebel, H. - 1908. Die Gastropoden. Wiss. Ergebn. Schwed. Südpol.-Exped. (1901-1903), 6: 1-112.

Witte, U. - 1996. Sponge biology and sediment biochemistry. Ber. Polarforsch., 190: 35. 